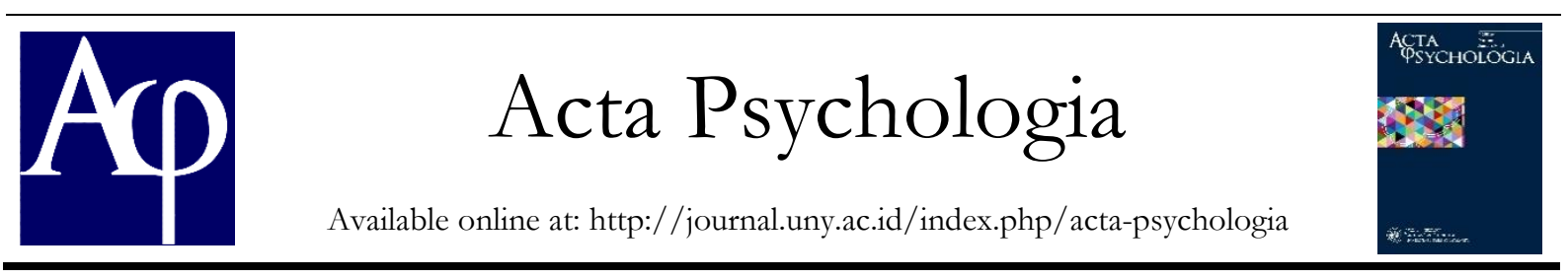

\title{
Identitas Sosial Pelajar Muhammadiyah dan Nadlatul Ulama
}

\author{
Anisa Nur Azizah \\ Program Studi Psikologi, Fakultas Ilmu Pendidikan Universitas Negeri Yogyakarta; Jl. Colombo \\ No. 1 Sleman Yogyakarta, 55281 \\ nurazizahanisah@gmail.com
}

\begin{abstract}
Abstrak
Penelitian ini bertujuan untuk mengetahui identitas sosial pada ORMAS Muhammadiyah dan Nahdlatul Ulama. Penelitian ini menggunakan metode kualitatif dengan pendekatan eksploratif. Terdapat empat informan yang telah diwawancari secara mendalam. Analisis dari penelitian ini menggunakan model analisis interaktif dari Miles dan Huberman. Hasil penelitian dari keempat informan memiliki tujuh poin, yaitu : 1) memiliki kesamaan terkait persepsi terhadap organisasi lain, 2) adanya pandangan positif dan negatif oranglain terhadap organisasi mereka, 3) terdapat kerjasama antar pengurus yang saling melengkapi dan membantu, 4) adanya rasa bangga terhadap identitas sosial mereka, 5) adanya tiga hal yang menjadi daya tarik bagi anggota, yaitu kerabat keluarga, kegiatan organisasi, dan cara berbicara pengurus di organisasi yang tegas, sopan dan santun, 6) mereka belum sepenuhnya mematuhi peraturan dan menerapkan nilai-nilai organisasi, serta 7) ditemukan kesamaan dari lingkungan sekolah, tempat tinggal, pola pemikiran dan kesamaan tujuan berorganisasi dengan pengurus lain.
\end{abstract}

Kata Kunci : identitas sosial, Muhammadiyah, Nahdlatul Ulama, eksploratif.

\begin{abstract}
This study aims to find out the social identity of ORMAS (Social Organization) Muhammadiyah and Nahdlatul Ulama. This study used qualitative method with an exploratory approach. There are four subjects that have been deep interviewed. The analysis of this study used interactive analysis model from Miles and Huberman. The results of the four informants had seven points, namely : 1) having similarities regarding their perceptions of other organizations, 2) theres is positive and negative views of others towards their organization, 3 ) there is cooperation between members who complement and helping each other, 4) there is pride on their social identity, 5) there are three things that became members' point of interest, namely family relatives, organizational activities, and organization members' way of speak that are firm and polite, 6) they have not fully obey the rules and apply organizational values, and 7) there is similarities from the school environment, residence, way of thinking, and similar purpose in organization with other members.
\end{abstract}

Keywords: social identity, Muhammadiyah, Nabdlatul Ulama, explorative

\section{Pendahuluan}

Identitas merupakan hal penting yang harus dimiliki oleh setiap orang. Hal ini penting, karena di dalam kehidupan sehari-hari orang tidak pernah lupa baik secara langsung maupun tidak langsung menanyakan "anda siapa" kepada seseorang yang baru dikenalnya.

Salah satu jenis identitas adalah identitas sosial. Identitas sosial adalah pengetahuan seseorang bahwa mereka termasuk dalam kelompok sosial (Hogg \& Terry, 2012). Individu yang memiliki identitas sosial yang tinggi tidak mudah terpengaruh orang lain dan memiliki konformitas yang rendah (Utami \& Silalahi, 2013), sehingga ia yakin dengan dirinya sendiri. Sementara itu, individu yang memiliki identitas sosial yang rendah cenderung mengalami kegelisahan, kebingungan, mudah terpengaruh, seperti penggunaan narkoba, budaya asing (Anonim, 2019), dan menunjukkan 
perilaku menyerang atau rejection sensitivity (Aisyah, 2018). Individu yang mengalami krisis identitas menjadi tidak tahu tujuan hidup dan mudah berganti keputusan serta bimbang dalam memutuskan sesuatu (Anonim, 2019).

Menurut Joseph S. Roucek dan Roland L. Warren (dalam Utami \& Silalahi, 2013) manusia menurut kodratnya selalu ingin hidup berkumpul dan berkelompok, sehingga manusia yang satu dengan lainnya senantiasa menjalin hubungan dan hidup bersama-sama. Hubungan antar manusia yang terjalin bersama-sama ini disebut dengan kelompok sosial.

Idealnya, menurut Jackson dan Smith (1999) semakin positif kelompok dinilai, maka semakin kuat identitas kelompok yang dimiliki dan akan memperkuat harga diri individu. Selain itu, individu yang memiliki identitas sosial yang tinggi juga tidak mudah terpengaruh orang lain dan memiliki konformitas yang rendah. Sementara itu, individu yang memiliki identitas sosial yang rendah cenderung mengalami kegelisahan, kebingungan, mudah terpengaruh.

Steinberg (dalam Anindyajati, 2013) menjelaskan bahwa krisis identitas dimulai dari masa remaja yang merupakan masa pencarian identitas, terutama perkembangan jati diri. Menurut tahap perkembangan Erikson ke lima, masa remaja yang berlangsung di antara rentang usia 10 sampai dengan 20 tahun disebut dengan tahap identity versus identity confusion Pada tahap ini terjadi krisis psikososial antara identitas diri dengan kebingungan identitas (Anindyajati, 2013).

Pada realitanya, krisis identitas sosial dialami para pelajar menyebabkan terjadi kenakalan remaja (tawuran, narkoba), fanatisme remaja K-Pop, membolos, merokok, merusak barang oranglain, dan seterusnya. Selain itu, kebingungan identitas juga terjadi pada anggota Muhammadiyah dan NU.

Muhammadiyah dan NU merupakan organisasi keagamaan terbesar di Indonesia. Kedua organisasi tersebut turut mempengaruhi kehidupan berbangsa dan bernegara, termasuk mempengaruhi identitas sosial sebagai warganya. Mayoritas penduduk Indonesia adalah anggota dari kedua ORMAS tersebut dan afiliasi dari kedua ORMAS (Ali, 2010). Salah satu bagian penting dari organisasi Muhammadiyah adalah IPM (Ikatan Pelajar Muhammadiyah) dan NU adalah IPNU (Ikatan Pelajar Nahdlatul Ulama) dan IPPNU (Ikatan Pelajar Putri Nahdlatul Ulama). Kedua ORMAS ini memiliki komponen organisasi yang berbeda.

Komponen dalam organisasi ini akan mempengaruhi proses identifikasi identitas sosial anggotanya, seperti struktur organisasi, nilai-nilai, ideologi, tokoh, dan sebagainya. Struktur dari organisasi IPM terdapat 10 bidang (Khoirudin, 2016) dan IPNU serta IPPNU memiliki 3 pengurus inti, 15 departemen, 6 lembaga dan dewan serta badan (Hasan, Ayyub, \& Syamwil, n.d.). Selain itu, tokoh dari dua organisasi ini pun berbeda, seperti IPM yaitu KH. Ahmad Dahlan dan IPNU serta IPPNU yaitu KH. Hasyim Asy'ari. Menurut Hogg (dalam Hogg \& Terry, 2012), identitas sosial adalah individu menerapkan nilainilai organisasi, berpartisipasi aktif dan mengembangkan rasa peduli serta menjadi bangga akan eksistensi kelompoknya.

$$
\text { Salah satu alumni SMP }
$$

Muhammadiyah di Yogyakarta menjelaskan bahwa terdapat ketidakselarasan aktivitas yang dilakukan dengan identitasnya. Padahal seluruh pelajar baik SD, SMP, SMA/SMK yang bersekolah di Muhammadiyah otomatis menjadi anggota IPM. Selain itu, ia juga merasa nilai-nilai keMuhammadiyahan tidak membekas pada dirinya. Pelajar Muhammadiyah belum menerapkan nilainilai organisasi yang mencerminkan keMuhammadiyahan.

Sementara itu, para anggota IPNU awalnya banyak yang mendaftar menjadi anggota, karena terpengaruh dari temantemannya. Calon anggota tersebut tidak 
tahu atau tidak mengenal mengenai organisasi IPNU terlebih dahulu, namun karena teman-teman di sekolahnya mengikuti IPNU akhirnya mereka kebanyakan konformitas untuk mengikuti organisasi IPNU tersebut.

Berdasarkan beberapa permasalahan di atas, peneliti membatasi permasalahan pada anggota IPM dan IPNU yang memiliki permasalahan dengan identitas sosial mereka, sehingga peneliti tertarik untuk melakukan penelitian tentang identitas sosial pelajar Muhammadiyah dan Nahdlatul Ulama.

\section{Metode Penelitian}

Penelitian ini menggunakan pendekatan kualitatif dengan jenis eksploratif. Penelitian ini dilaksanakan melalui daring dan luring. Pengambilan data luring dilakukan di IPM Cabang Wirobrajan dan IPNU Cabang Pleret serta IPPNU Cabang Banguntapan di Daerah Istimewa Yogyakarta. Pengambilan data daring dilakukan dengan menggunakan WhatsApp. Waktu penelitian dilakukan pada bulan Maret hingga Mei 2020. Subjek pada penelitian ini adalah pelajar organisasi keagamaan yaitu dari Muhammadiyah ada Ikatan Pelajar Muhammadiyah (IPM) dan Nadlatul Ulama adalah IPNU (Ikatan Pelajar Nahdlatul Ulama) dan IPPNU (Ikatan Pelajar Putri Nahdlatul Ulama) cabang di Daerah Istimewa Yogyakarta. Identitas subjek dapat dilihat dalam tabel 1.

Cara pengambilan subjek pada penelitian ini menggunakan purposive sampling dengan syarat sebagai berikut : 1) berusia 12-24 tahun. 2) seorang pelajar, 3) anggota atau pengurus IPM dan IPNU atau IPPNU.

Peneliti menggunakan rentang usia 12 hingga 24 tahun, karena mengacu pada batasan usia remaja menurut WHO. Lalu, peneliti menggunakan seorang pelajar, karena sesuai dengan tujuan penelitian yaitu untuk mengetahui identitas sosial antara pelajar pada ORMAS.
Tabel 1. Identitas Subjek Penelitian

\begin{tabular}{lccll}
\hline Subjek & $\begin{array}{l}\text { Jenis } \\
\text { Kelamin }\end{array}$ & Usia & Jabatan & Periode \\
\hline NR1 & P & 17 & Ketua IPPNU & 3 tahun \\
MM1 & L & 18 Bendahara \\
& \multicolumn{2}{l}{ IPPNU } & 3 tahun \\
RS2 & L & 17 & Ketua IPM & 6 tahun \\
SF2 & P & 16 & Sekretaris IPM & 6 tahun \\
\hline
\end{tabular}

Peneliti menggunakan anggota atau pengurus IPM dan IPNU atau IPPNU karena keduanya merupakan bagian dari pelajar Muhammadiyah dan Nahdlatul Ulama. NR dan MM merupakan informan dari IPNU dan IPPNU, sedangkan RS dan SF merupakan informan dari IPM.

Teknik pengumpulan data pada penelitian ini menggunakan data primer yaitu peneliti yang melakukan wawancara terhadap anggota kedua ORMAS keagamaan. Pada penelitian ini akan melibatkan anggota ORMAS dari pelajar Muhammadiyah dan pelajar Nahdlatul Ulama. Peneliti menggunakan wawancara terstruktur dan mendalam dengan menggunakan aspek - aspek dari identitas sosial.

Pada penelitian ini, instrumen penelitiannya adalah peneliti sendiri (human instrument). Menurut Denzin dan Licoln (2009). menjelaskan bahwa dalam penelitian kualitatif, peneliti bertindak sebagai instrumen utama, yaitu sebagai pelaksana, pengamat, dan sekaligus sebagai pengumpul data. Peneliti sebagai instrumen utama menggunakan pedoman wawancara identitas sosial untuk pengambilan data penelitian. Pedoman wawancara tersebut berisi aspek-aspek dari identitas sosial.

Teknik analisis data pada penelitian ini menggunakan Miles dan Huberman (1992), dimana terdapat tiga langkah pengolahan data kualitatif, yakni reduksi data (data reduction), penyajian data (data display), dan penarikan kesimpulan (conclusion drawing and verification).

Data yang diperoleh dari wawancara dilakukan penyederhanaan, kemudian disajikan dalam bentuk teks naratif. Peneliti 
akan membentuk tabel hasil wawancara, sehingga akan mudah dibaca. Hasil wawancara, dilakukan pembahasan dengan teori dan peraturan mengenai penelitian, sehingga akan diperoleh suatu kesimpulan dalam penelitian yang menggambarkan secara detail satu persoalan yang diteliti yaitu identitas sosial pada ORMAS.

\section{Hasil Penelitian dan Pembahasan}

Masa remaja identik dengan masa pencarian atau pembentukan identitas. Pembentukan identitas ini bersifat sosial, karena dipengaruhi oleh interaksi dengan lingkungan sekitar. Proses pencarian atau pembentukan identitas sosial pada remaja diwadahi lingkungan dengan adanya suatu kelompok atau komunitas. Pada remaja pelajar, mereka terfasilitasi dengan organisasi yang ada di sekolahnya atau di luar sekolahnya.

Pada sebuah organisasi terdapat hubungan antara anggota kelompok dengan kelompok perbandingan lainnya (Baron \& Byrne, 2004). Hal ini berguna untuk mengategorikan diri sebagai anggota kelompok yang dirasakan ketika berada di lingkungan sosial (Kite \& Whitley, Jr, 2016).

Hasil penelitian yang didapatkan peneliti adalah keempat subjek memiliki kesamaan terkait persepsi terhadap organisasi lain. Persepsi tersebut adalah mereka menilai bahwa organisasinya dengan organisasi lain sama saja karena gurunya sama dan ajarannya bersumber dari agama Islam. Selain itu, mereka menilai organisasi lain masing-masing juga memiliki ciri khas. Akan tetapi, tempat berdakwahnya saja yang berbeda. Organisasi Muhammadiyah berdakwah dari kota, sehingga lebih modern. Sebaliknya, organisasi Nahdlatul Ulama dari desa, sehingga lebih tradisional. Hal tersebut dipaparkan NR dalam kutipan wawancara sebagai berikut,

"Iya sebenernya sama Mbak. Sebenermya gurunya guru kita th sama. Cuman cara menyampaikan kita yang berbeda, berbeda tempat berjuangnya saja. Kalau mereka di daerah kota, kalau NU masih di daerah tradisional. Jadi, cara penyampaian mereka juga Mubammadiyah mungkin lebih modern, karena mereka berangkat dari kota tidak seperti didesa."

NR merasa organisasi lain yang berawal dari daerah kota menjadi lebih banyak memiliki keuntungan dan lebih mudah diterima daripada di pedesaan, sehingga organisasi lain lebih mudah berdakwahnya. Hal ini terjadi kesenjangan antar pengurus organisasi, di mana ia merasa organisasinya tidak memiliki peluang yang sama dengan organisasi lain. Namun, hal tersebut menunjukkan bahwa semakin besar perbedaan yang dirasakan, semakin besar kemungkinan seseorang untuk mengategorikan diri pada dimensi yang membedakan dan mengambil identitas sosial yang terkait dengan dimensi itu (Kite \& Whitley, Jr, 2016).

NR menilai IPNU memiliki ciri khas yang membedakan dengan organisasi lain. Ciri khas menurut NR adalah organisasinya sering melakukan ziarah kubur, organisasinya membedakan antara putra dan putri menjadi organisasi otonom sendiri-sendiri, organisasinya tidak ada perbedaan gender untuk menjadi pemimpin. Selanjutnya, persepsi orang lain terhadap organisasi NR dan MM terbagi menjadi dua, dari pandangan positif dan pandangan negatif.

Pendapat positif dari orang lain terhadap Nahdlatul Ulama adalah bahwa sumber keilmuan sesuai ajaran Rasulullah. Masyarakat luas pun juga menilai positif terhadap organisasi MM. Masyarakat menilai positif, karena kegiatan yang diadakan oleh organisasi MM selalu menarik. Hal tersebut memperkuat identitas sosial pada NR dan MM, karena semakin positif kelompok dinilai, maka semakin kuat identitas kelompok yang dimiliki dan akan memperkuat harga diri individu tersebut (Jackson \& Smith 1999, dalam Absari, 2013). 
Pendapat negatif dari orang lain terhadap Nahdlatul Ulama adalah NU jaman sekarang berbeda dengan jaman dahulu. Menurut NR dari segi amalan dan ketidaksukaan orang lain terhadap pemimpin organisasi, seperti tahlilan yang menjadi amalan bid'ah. Selain itu pandangan tokoh senior NU terhadap IPNU sekarang liberal dan berjalan mengikuti jaman. Hal tersebut menyebabkan identitas sosial yang rendah dan NR serta MM menjadi sempat mengalami kebingungan identitas sosial.

Menurut Pemimpin Nahdlatul Ulama memandang pengurus IPPNU dan IPNU sudah tidak sesuai dengan ajaran NU pada jaman dahulu. Bagi para pemimpin, cara berdakwah pada jaman dahulu juga lebih baik diterapkan pada jaman sekarang, sehingga terhindar dari fitnah organisasi lain. Padahal, NR dan pengurus lainnya mengikuti jaman modern agar mudah diterima dengan mudah pada masyarakat luas. Pandangan-pandangan tersebut sesuai dengan Kurt Lewin (1951), di mana terjadi dinamika kelompok digambarkan sebagai cara kelompok dan individu bertindak dan bereaksi terhadap perubahan keadaan (Baron \& Byrne, 2012).

Kelompok yang baik dicirikan dengan tingginya kuantitas dan kualitas interaksi antar anggota kelompok, sehingga penting bagi kelompok untuk membangun dan menjaga hubungan antar anggota kelompok (Forsyth, 2006). Dalam hal ini, MM berbagi ilmu dengan anggota organisasi lain. Ia menerapkan hal baik yang ada di organisasinya ke organisasi lain, seperti sharing manajemen keuangan organisasinya kepada organisasi lain.

Banyak kegiatan dari organisasi MM yang melibatkan anggota di luar organisasi, seperti lomba-lomba di Hari Santri yang menjadi ciri khas organisasi IPNU. Hari santri memiliki kegiatan yang berbeda tergantung tingkatan organisasinya. Hari santri sudah menjadi ciri khas ORMAS NU dan Muhammadiyah. Kegiatan tersebut menjadi cara dari masing-masing ORMAS untuk saling mengevaluasi, sehingga para anggota dapat lebih termotivasi lagi dalam mengerjakan tugas kelompok dan meningkatkan komitmen mereka terhadap organisasi (Forsyth, 2006).

Menurut Jackson \& Smith, pada sebuah kelompok membutuhkan rasa keberhargaan menjadi bagian dari suatu kelompok tersebut, individu akan mengidentifikasi dirinya berdasarkan perasaan yang ditimbulkan dengan anggota lain (Baron \& Byrne, 2004).

MM sudah mengetahui organisasinya sejak usia SD. Ia tertarik dengan kegiatan di organisasinya. Kegiatan organisasi yang menarik menurut subjek seperti Majelis bergilir, kegiatan harian dan program kerja. Selain itu, organisasinya memiliki event tahunan. MM Sejak SMP, sudah mengikuti event organisasinya, sehingga identitas sosial mendorong seseorang melakukan aktivitas yang sesuai dengan identitasnya (Haslam, 2004). Ia merasa senang dan bangga menjadi bagian dari organisasinya. Apalagi melihat cara berbicara anggota di organisasinya membuat MM semakin tertarik dengan organisasinya.

NR tertarik bergabung menjadi bagian dari IPPNU karena saudara kandungnya yang sebelumnya sudah menjabat menjadi pengurus IPPNU Cabang Pleret. Saudara kandung NR tersebut merupakan pendiri dari IPPNU Cabang Banguntapan. Saudara kandungnya mengajak adik-adiknya untuk turut serta dalam membantu pendirian organisasi Cabang Banguntapan.

Hal tersebut dipaparkan NR dalam kutipan wawancara sebagai berikut:

"Jujur tu, dulu kan kakak saya pengurus IPPNU tapi nggak di Banguntapan tapi di Pleret. Habis itu belian setelah jadi ketua, selesai jadi ketua di sana dapet amanat dariyang atas itu buat dirïn di kecamatan Banguntapan. Habis itu kan kaka saya yang bantu buat bikin itu terus ya adikadiknya juga disurub ikut." 
NR cenderung menurut dengan saudara kandungnya sehingga ajakan dari saudara kandungnya untuk turut berpartisipasi tersebut menjadi salah satu daya tarik NR terhadap organisasi IPPNU. Dalam kesehariannya, NR sering melihat saudara kandungnya berorganisasi. Saudara kandungnya yang sering melakukan banyak kegiatan membuat NR merasa ingin seperti dirinya.

Pada hal ini NR melakukan teori belajar sosial (Santrock J. W., 2004), di mana ia memberikan perhatian pada setiap aktivitas saudara kandungnya, lalu terjadi secara berulang hingga tersimpan di memori dan mereproduksi perilaki yang sama di organisasi NR sendiri. NR diberi penguat atau motivasi berupa dorongan dari keluarga dan adanya pengaruh dari temantemannya yang mengajaknya pula untuk bergabung ke dalam organisasi IPPNU. Selain saudara kandungnya, orangtua NR pun juga menjadi bagian dari organisasi ranting Nahdlatul Ulama. Namun, hanya saja ibunya yang tidak terlalu aktif di sistem organisasinya.

Menurut NR kegiatan-kegiatan di Nahdlatul Ulama itu juga menjadi daya tarik sendiri. Sejak kecil ia pun sudah mengikuti kegiatan-kegiatan tersebut. Kegiatankegiatan tersebut merepresentasikan dari identitas sosial kelompok (Nahdlatul Ulama) (Baron \& Byrne, 2004), sehingga NR merasa bahwa organisasinya juga memberikan wadah bagi pelajar untuk mengembangkan dirinya.

Hal ini dipaparkan NR dalam kutipan wawancara sebagai berikut,

"Hmm kalau menurutku, iya dari kegiatannya misalnya kayak hadrohan, sholawatan kemarin itu kayak udab kan dulunya aku pas waktu kecil sering ikut pengajian yahusyan atau apa yang sholawat-sholawat kayak gitu. habis itu juga ada wadah. Ibaratnya ada wadah dikalangan pelajar jadinya juga bisa ikut dan dengerin jadi ya kayak tertarik dan gitu sama dilibat dari kegiatan ekstranya gitu kayak outbond gitu kan jadi kayak seru ya jadi tertarik. buat ikut nih ya udah jadi daftar aku mbak."
Teori identititas sosial menjelaskan bahwa karyawan memaknai identitas dirinya ke dalam berbagai kategori sosial seperti keanggotaan dalam suatu kelompok atau organisasi berdasarkan peran sosial dan hubungan peran (Hogg \& Terry, 2012).

NR setelah terjun di organisasi dan turut berjuang dalam mendirikan IPPNU Cabang Banguntapan, kata-kata mutiara dari tokoh Nahdlatul Ulama menjadi motivasi NR dalam berorganisasi. Sejarah berdirinya Nahdlatul Ulama menjadi penyemangat NR dalam berorganisasi, sehingga ia merasa bangga menjadi bagian dari IPPNU Banguntapan. Jika individu merasa bangga terhadap organisasinya, maka fungsi identitas sosial baginya terpenuhi. Sebab, individu memakai identitas sosialnya sebagai sumber kebanggaan diri dan harga diri (Jackson \& Smith 1999, dalam Absari, 2013).

NR merasa berat berjuang di organisasinya selama proses awal di organisasi. Realita NR di organisasi yang tidak seperti ekspetasinya. Menurut NR, organisasi membutuhkan sesuatu yang menarik untuk mengajak orang lain gabung di organisasinya. Sempat NR merasa malu di awal keanggotaannya, sebab mayoritas teman sekolah NR ada orang Muhammadiyah. NR mengalami identitas sosial kronis. Identitas sosial kronis ini terjadi ketika individu sebagai anggota kelompok minoritas merasa berbeda di lingkungan yang sebagian besar situasi antar kelompok sama (Kite \& Whitley, Jr, 2016). Status kelompoknya yang minoritas ini membuat NR merasa cemas terlepas dari identitas lain.

Kepribadian dan nilai-nilai yang berbeda-beda pada setiap orang dapat mempengaruhi identitas sosialnya. Beberapa orang mungkin memiliki kecenderungan untuk mengidentifikasi lebih kuat dengan kelompok-kelompok yang mereka miliki terlepas dari faktor situasional apa pun yang mungkin beroperasi (Kite \& Whitley, Jr, 2016). 
NR mengakui ajaran Nahdlatul Ulama adalah ajaran yang benar. Pengakuan tersebut ia dapatkan melalui kegiatan kaderisasi yang berisi penyampaian materimateri mengenai ber-Nahdlatul Ulama. Materi tersebut menjadi dasar utama NR untuk tetap bertahan di organisasi apapun masalahnya. Seperti daya tarik MM yang berawal dari dirinya menyukai hal baru baik pengalaman dan teman. MM merasa setiap muslim wajib memiliki ilmu. Ia tertarik belajar ilmu sosial dan agama di organisasi. Hal tersebut membuat NR dan MM merasa yakin dengan identitas sosialnya.

NR merasa antar anggota saling memiliki ikatan. Ia mendapat sistem pendukung di organisasi dan menjadi memiliki banyak relasi setelah bergabung di IPPNU. Organisasi IPPNU memberikan wawasan dan pemahaman terkait perbedaan individu kepada NR, sedangkan MM mendapat banyak manfaat dari keikutsertaan organisasi daripada tidak ikut. Salah satu manfaatnya adalah di organisasi MM dapat turun langsung ke masyarakat setiap bulan Ramadhan. Dengan demikian, kohesi kelompok meningkat sebab terjadi ikatan interpersonal anggota yang mengikat suatu kelompok untuk bersama-sama (Forsyth, 2006).

Norma dan nilai-nilai organisasi akan menghasilkan perilaku anggota kelompok ketika mereka berusaha mencapai tujuan dan berbagi keyakinan yang sama (Baron \& Byrne, 2004). Para anggota dan pengurus yang tentunya perlu menerapkan nilai-nilai organisasi dan mematuhi norma yang berlaku di organisasi, sehingga mereka akan memiliki keyakinan terhadap organisasinya. Bentuk keyakinan tersebut dimanifestasikan ke dalam sebuah tindakan.

Pada penelitian ini ditemukan keyakinan yang saling terkait baik terhadap organisasi maupun antar pengurus. Pertama yang akan dibahas adalah keyakinan terhadap organisasi melalui representasi keyakinan NR1, MM1 terhadap nilai-nilai organisasi.
NR dan MM bersama pengurus lain memiliki keyakinan yang saling terkait di dalam organisasi. Ia meyakini bahwa organisasinya sebagai sumber berpikir dan bertindak terhadap Tuhan. Hal tersebut dipaparkan MM dalam kutipan wawancara sebagai berikut,

"Diniyyah/Keagamaan: Taubid (al-taubid) merupakan keyakinan yang kokoh terbadap Allah SWT sebagai sumber inspirasi berpikir dan bertindak."

NR memiliki keyakinan terhadap nilai-nilai organisasi, seperti toleransi, tabayyun, keadilan, kerjasama, kekompakan, kepedulian. Nilai lain dalam organisasi juga terdapat nilai kemanusiaan. Walau tidak seiman tetap menjalin hubungan baik seperti lingkungan sekolah NR1 yang lebih banyak orang-orang non Muslim. Akan tetapi, NR1 merasa belum bisa maksimal menerapkan nilai kemanusiaan.

Salah satu contoh kegiatan dari nilai kemanusiaan yaitu kegiatan bantu donasi, ia merasa belum bisa membantu orang lain secara finansial. Selain nilai kemanusiaan, NR1 kurang bisa menerapkan nilai keadilan pada dirinya dan orang lain. Berbeda dengan MM yang meyakini nilai-nilai organisasi yang menurutnya merupakan penjabaran dari prinsip organisasi.

Kejujuran, beriman, menjadi makhluk sosial, dan berbuat baik adalah penjabaran dari nilai tauhid. Selain itu, MM merasa setiap muslim wajib memiliki ilmu, sehingga keilmuan mendorongnya untuk berprestasi dan menjadi pelopor.

Keikutsertaan MM dalam turun langsung ke masyarakat merupakan keyakinannya pada nilai organisasi. Nilai organisasi tersebut adalah nilai sosial kemasyarakatan yang mendorong MM untuk bertoleransi dan bermanfaat untuk masyarakat.

Keyakinan NR dan MM tersebut sesuai dengan teori Baron yang menunjukkan bahwa identitas sosial mendukung organisasi yang 
merepresentasikan identitasnya (Baron \& Byrne, 2004).

Kedua, NR dan MM berusaha mematuhi peraturan organisasi. Salah satu cara NR mematuhi peraturan organisasi adalah berbicara sopan santun dan menggunakan seragam batik Nahdlatul Ulama dan PDH yang menjadi identitas dari IPPNU. Menyanyikan lagu mars organisasi sebelum dimulai rapat rutin, sedangkan MM mematuhi peraturan dengan mengusahakan berangkat rapat tepat waktu, jika berhalangan hadir meminta ijin dan rutin membayar iuran kas organisasi.

Menurut Forsyth, para anggota atau pengurus kelompok saling memiliki ketergantungan satu sama lain. Setiap anggota mempunyai pengaruh kepada anggota lainnya (Forsyth, 2006). Pada realitanya, waktu pada setiap kegiatan masih saja berjalan molor. Saat satu pengurus terlambat datang atau masih sedikit pengurus yang datang rapat maupun kegiatan, maka akan mempengaruhi jalannya rapat atau kegiatan itu berlangsung.

Pada saat kegiatan rapat rutin, tidak ada pembagian tugas sebelum dimulainya rapat. Hal ini dapat menyebabkan rapat berjalan tidak teratur dan tidak efektif. Padahal, suatu kelompok penting dalam membagi peran kepada tiap pengurusnya. Peran-peran ini berkaitan dengan tugas dan memungkinkan kelompok untuk bekerja lebih efektif (Forsyth, 2006).

Pengaruh antar anggota yang terjadi pada IPNU dan IPPNU juga terjadi pada permasalahan pribadi. Permasalahan pribadi bisa mempengaruhi organisasi, tergantung orang yang memiliki masalah tersebut. Sebagai contoh masalah yang dialami NR, kalau ada oknum yang bermasalah di organisasi mempengaruhi anggota yang lainnya.

NR merasa ada satu anggota yang tidak menyukai kebijakan organisasi. Satu anggota tersebut mempengaruhi anggotaanggota lain yang tidak tahu apa-apa. Jadi anggota yang terpengaruhi tersebut mempertanyakan kepada NR, mengapa bisa terjadi. Hal tersebut membuat resah NR, karena anggota yang tidak tahu apa-apa menjadi turut ikut tidak menyukai kebijakan organisasi.

Pengaruh masalah pribadi lain yang terjadi adalah jika ada satu anggota (A) sebagai contoh atau panutan di organisasi memiliki masalah dengan satu anggota lain (B) di dalam organisasi. Hal tersebut mempengaruhi permasalahan di organisasi. Misalnya, si A mau datang rapat atau kegiatan di organisasi jika si B tidak hadir dan begitu sebaliknya, sehingga para anggota atau pengurus kelompok saling memiliki ketergantungan satu sama lain (Forsyth, 2006).

Apabila si A pada akhirnya tidak datang menyebabkan teman-teman si A yang juga anggota turut tidak datang juga. Hal ini membuat NR tidak menyukai jika ada masalah pribadi dibawa ke organisasi. Pengaruh permasalah tersebut juga terjadi pada MM, namun MM lebih memilih untuk bersikap ikhlas, setia, dan memaafkan sesama pengurus. Bagi MM, masalah internal sebagian orang harus kembali lagi ke tujuan awal mereka masuk organisasi. Apalagi setelah dilantik, mereka harus bertanggung jawab dengan masalah pribadinya.

Menurut Haslam (2004), dalam identitas sosial anggota atau pengurus harus memiliki kesamaan antar anggota dalam suatu kelompoknya. NR memiliki kesamaan dengan pengurus lain dalam hal pola pemikiran terhadap suatu hal. Salah satu contoh dari pemikiran yang sama adalah persiapan regenerasi organisasi.

Kesamaan lain antar pengurus adalah subjek yang suka membicarakan orang yang tidak menyukai organisasinya. MM dan pengurus lainnya memiliki kesamaan tempat sekolah dan tempat tinggal. Mayoritas pengurus memiliki tempat tinggal di daerah yang sama. Ia menilai dirinya berperan sekali untuk organisasinya. 
NR merasa masih ada perbedaan antara nilai pribadi dengan nilai organisasi. Perbedaan antara nilai pribadi dengan nilai organisasi membuat dirinya merasa tidak nyaman. Ia memandang dirinya masih egois, padahal organisasinya mengutamakan kebersamaan.

NR masih saja terus memikirkan organisasi sendiri. Padahal di organisasinya apapun pekerjaannya ditanggung bersama. NR juga selalu memikirkan dahulu gagasannya sebelum disampaikan ke forum organisasi. Akan tetapi, NR menginginkan jika semua keinginan dan permintaannya itu disetujui oleh semua pengurus. Namun, NR sadar bahwa seharusnya tidak seperti itu.

Hal tersebut menunjukkan bahwa NR telah mengategorisasi dirinya terhadap lingkungan sosial. Salah satu hasil kategorisasi diri adalah bahwa dengan meningkatnya identitas sosial dan penurunan identitas pribadi, identitas kelompok, tujuan kelompok, dan pengaruh anggota grup lain menjadi lebih penting daripada identitas pribadi, tujuan pribadi, dan motif-motif pribadi dalam membimbing keyakinan dan perilaku (Kite \& Whitley, Jr, 2016).

MM juga cenderung bersikap tidak peduli dengan anggapan keberadaaannya di organisasi dan tidak peduli dengan penilaian orang lain di organisasinya. MM merasa setiap orang punya haknya masing-masing. Hal ini dipaparkan MM dalam kutipan wawancara sebagai berikut,

"Kalau aku gak mikir ini sih. Di organisasi ya ada kumpul ya ikut. Jangan mikirin itu nek aku soalnya bal kek, gitu kembali ke setiap orang masing masing."

MM merasa kesal terhadap keberadaannya di organisasi. Ia merasa ada saja pengurus yang tidak menganggap keberadaannya di organisasi. Kadang MM juga kesal terhadap pengurus yang jarang terlihat di rapat rutin, namun terlihat saat pelaksanaan kegiatan. Perasaan tersebut meningkatkan identifikasi MM terhadap identitas sosialnya.

NR memandang dirinya sebagai bagian dari IPPNU adalah individu yang mudah bergaul, ramah dan tidak membedabedakan. Selain itu, NR adalah orang yang pemaaf. Namun, ia kurang bisa mengatur waktu. Ketika hari esok itu jadwal ujian, malamnya NR masih ikut acara organisasi. Seharusnya, waktu malam digunakan untuk belajar tetapi untuk memikirkan organisasi.

Menurut Turner (1975, dalam Haslam, 2004) identitas sosial mendorong seseorang melakukan aktivitas yang selaras dengan identitasnya. MM memandang dirinya mengamati kinerja pengurus lain. Ia belajar cara menghadapi masalah di saat tidak memiliki banyak waktu dari pengurus lain. MM berusaha untuk meminta bantuan jika tidak bisa dikerjakan sendiri.

Cara MM mengevaluasi dirinya pun dengan masukan dari pengurus lain. Lalu, NR mengevaluasi dirinya dengan minta pendapat dari pengurus atau anggota lain. NR menyaring masukan dari orang lain dan mencari solusi terbaik untuk dirinya. Evaluasi diri tersebut dapat meningkatkan komitmen terhadap kelompok (Forsyth, 2006).

Sementara itu pada RS, ia ragu-ragu ketika ditanya memiliki teman di luar organisasinya. Ia merasa ruang lingkupnya hanya di daerah asrama dan sekolah Muhammadiyah saja. Namun, ia menilai organisasi lain bagus. Baginya, setiap organisasi memiliki ciri khas masingmasing. Seperti, ciri khas organisasi RS ada pada pakaian jasnya dan organisasi RS merupakan satu satunya organisasi pelajar di ORMAS Muhammadiyah. Hal ini berguna untuk mengategorikan diri sebagai anggota kelompok yang dirasakan ketika berada di lingkungan sosial (Kite \& Whitley, Jr, 2016).

RS menilai setiap organisasi lain juga memiliki hak untuk berdakwah. Tiap organisasi sudah punya tempatnya sendiri untuk berdakwah, sehingga sangat diperlukan untuk menjaga toleransi antar umat beragama. 
Hal ini dipaparkan SF dalam kutipan wawancara sebagai berikut,

"Biasa aja sib. Yaa sama organisasi tadi, kalau aku sih paham aku punya meja sendiri, aku juga paham mereka punya meja sendiri. Boleh berdakwah, boleh saling mempengarubi tapi jangan sampe rebut sendiri gitu. Jadi kalau man berdakwah gitu mau mempengarubi gitu yaudah, cuman kalau sampe akbirmya bikin konflik, bikin rebut ya jangan sampe gitu lab. Maksudnya kita tau punya batasan, punya ruang lingkup sendirisendiri gitu.”

Berbeda dengan SF yang memiliki pandangan terhadap organisasi lain bahwa mereka lebih fokus pada kegiatannya saja, sehingga cakupan kebermanfaatannya kurang luas. Akan tetapi SF menilai antar organisasi saling membantu dan saling menolong.

Banyak teman SF yang menjadi aktivis di organisasi lain, sehingga SF juga terpengaruh dengan lingkungan teman sebayanya. SF bersama temantemannya saling bertukar cerita antar organisasi. Hal ini menunjukkan bahwa organisasi SF baik, karena membangun dan menjaga hubungan antar angota kelompok (Forsyth, 2006).

Pada aspek ini ditemukan mengenai rasa keberhargaan individu ketika individu tersebut menjadi bagian dari suatu kelompok (Baron \& Byrne, 2004). Pada aspek akan dijelaskan latar belakang SF dan RS yang menjadi landasan mereka tertarik dengan organisasi IPM.

RS dan SF memiliki daya tarik yang sama dengan organisasi mereka. Kesamaan daya tarik tersebut adalah adanya pengaruh dari kerabat keluarga mereka masingmasing. RS ingin menjadi seperti kedua Kakaknya yang memiliki jabatan tinggi di organisasi IPM namun beda tingkatan, sedangkan SF juga ingin menjadi seperti Ayah dan Omnya yang menjadi pengurus di organisasi Muhammadiyah yang sama namun beda tingkatan. Hal tersebut menunjukkan bahwa peran keluarga berpengaruh penting terhadap perkembangan psikososial anak.

RS merasa kecewa yang ditolak di organisasi kedua Kakaknya, padahal kakaknya menjabat sebagai ketua dan sekretaris organisasi. Perasaan kecewa tersebut membuat RS tidak menyerah dengan keadaan, namun menjadi gigih dalam menggapai keinginannya untuk menjadi bagian dari IPM. Ia ingin menunjukkan kepada kedua kakaknya bahwa dirinya tetap bisa berperan penting di organisasi, sehingga ia menerima tawaran menjadi Kepala Departemen dan sekarang menjadi Ketua Umum IPM Wirobrajan.

RS yang menjadi anak ketiga dari tiga bersaudara tentunya merasa harus menjadi lebih baik daripada kedua saudara kandungnya. Hal ini terjadi sibling rivalry antara RS dan kedua saudaranya. Mereka berlomba-lomba untuk menjadi yang terbaik. Namun, RS merasa IPM berperan banyak kepada pondoknya, sehingga kontribusi dan tanggung jawab MM membuat dirinya bangga atas pencapaiannya. Ia berusaha melampaui batas kemampuan dirinya. Hal tersebut menunjukkan bahwa kemampuan efikasi RS baik. Jika suatu kelompok memiliki efikasi kelompok yang tinggi, maka tingkat motivasi untuk bekerja juga meningkat (Forsyth, 2006).

SF mengalami masa kecil yang buruk di saat duduk di bangku Sekolah Dasar (SD) sempat menjadi korban bullying. Hal tersebut membuat dirinya menjadi individu yang pendiam dan menarik diri dari lingkungan. Padahal, SF sangat ingin menjadi seperti ayahnya. Impian SF bisa bergabung menjadi bagian dari IPM menjadi motivasi tersebar untuk menunjukkan kepada teman-temannya bahwa dirinya juga bisa seperti mereka yang memiliki banyak teman.

Pengalaman-pengalaman masa kecil ini tersimpan di dalam long term memory $\mathrm{SF}$, sehingga terbawa hingga usia remaja. 
Hal tersebut dipaparkan SF dalam kutipan wawancara sebagai berikut,

"Nab dari TK sampe SD tu aku korban bully mbak, rata-rata mandang aku terlalu pendiem dan alim jadi kek susah bergaul, padahal ya enggak. Ya pas SD aku punya impian harus bisa di IPM karna aku pikir dengan aku di organisasi aku bisa buktiin kalo aku ni juga bisa kok bergaul dengan siapapun, bukan untuk. pamer atau cari muka, tapi dengan IPM aku bisa ngerasain bener-bener lika likunya, apalagi di ranting kan di sekolah ada nakal ada yang anteng, ya aku berusaha bisa memposisikan diriku di lingkungan mana pun."

SF saat bergabung di organisasi, ia merasa hidupnya menjadi lebih bermakna. SF merasa masyarakat memandang buruk pada pelajar, sehingga melalui organisasi bisa menjadi generasi yang cerdas. Hal ini sesuai dengan nilai kemasyarakatan Muhammadiyah, di mana mewujudkan masyarakat Islam terlebih pelajar yang sebenar-benarnya atau the real Islamic society (Anonim, 1997).

RS berterimakasih kepada organisasinya sudah menerima dirinya dan bersyukur berada di IPM. Selanjutnya, SF merasa organisasinya memberikan warna baru bagi kehidupannya, sehingga ia bisa berubah menjadi dirinya sendiri dan bahagia serta bangga berada di organisasinya. Hal tersebut membuktikan bahwa individu tidak mudah terpengaruh dari orang lain dan memiliki konformitas yang rendah, sehingga menunjukkan identitas sosial yang tinggi (Utami \& Silalahi, 2013).

RS meyakini bahwa organisasinya mencerminkan keislaman pada umumnya. Ajaran Islam berarti juga menerapkan nilainilai organisasi. RS pun juga mengajak pengurus lain untuk menegakkan kebenaran.

Menurut Baron, norma dan nilainilai organisasi akan menghasilkan perilaku anggota kelompok ketika mereka berusaha mencapai tujuan dan berbagi keyakinan yang sama (Baron \& Byrne, 2004). RS menyebutkan nilai organisasi yang ia yakini ada 3 hal. Tiga hal tersebut adalah berakhlak mulia, berilmu, terampil. Tiga hal nilai organisasi ini dimanifestasikan menjadi bidang PIP (Pengkajian Ilmu Pengetahuan), KDI (Kajian dan Dakwah Islam) dan Pengkaderan. Lalu, RS menyebutkan tujuan IPM tidak jauh beda dari Muhammadiyah yaitu lebih ke kembali ke masyarakat dan SF meyakini bahwa nilai-nilai organisasinya ada lima.

Lima nilai yang diyakini SF adalah keislaman, kekeluargaan, kepedulian sosial, pendidikan dan kebudayaan. RS berpikir bahwa nilai-nilai organisasi perlu diperbaiki. Setiap organisasi otonom Muhammadiyah tidak bisa disamakan karena kondisi organisasi yang berbeda dan fleksibel. Pada faktanya, di lapangan tidak berjalan sesuai dengan nilai-nilai organisasi.

SF memiliki penilaian yang sama dengan RS, ia merasa ada yang kurang dinilai-nilai organisasinya. SF mengatakan bahwa tidak semua kegiatan atau program kerja mencerminkan nilai- nilai organisasi. Padahal, di dalam dinamika kelompok membutuhkan pekerjaan yang memuaskan. Pekerjaan yang memuaskan ini akan menimbulkan rasa kebermaknaan dan tanggung jawab terhadap capaian serta pengetahuan terhadap hasil pada masingmasing pengurus (Forsyth, 2006). Jika RS dan SF merasa kurang bermakna kegiatan atau program kerja dari organisasi sendiri, maka hal tersebut tidak akan sampai pada tujuan organisasi.

Kelompok yang baik dicirikan dengan tingginya kuantitas dan kualitas interaksi antar anggota kelompok, sehingga penting bagi kelompok untuk membangun dan menjaga hubungan antar anggota kelompok (Forsyth, 2006). RS bersama pengurus lainnya dalam bekerja di organisasi saling membantu dan saling melengkapi. Begitu pun juga antar bidang di organisasi. Sementara itu, SF juga menjadi lebih peduli pada orang lain, menjadi lebih 
tepat waktu dalam beribadah, berhati-hati dalam berbicara, bersikap sopan terhadap pengurus lain dan saling mengingatkan sesama pengurus.

RS meyakini bahwa hubungan antar senior dan junior di organisasi mempengaruhi perilaku RS. Baginya, hubungan interpersonal non formal di organisasi itu penting. Hubungan interpersonal itu yang membuat dirinya tahu keadaan sebenarnya teman-teman pengurus organisasi. Setiap anggota mempunyai pengaruh kepada anggota lainnya (Forsyth, 2006). Akan tetapi, RS merasa seorang pimpinan pun masih ada yang tidak menjalankan nilai-nilai organisasi, sehingga ia merasa kurang sesuai dengan nilai-nilai organisasi. Hingga saat ini, RS belum berperilaku sesuai nilai-nilai organisasi. Padahal Identitas sosial adalah individu menginternalisasikan atau menerapkan nilai-nilai organisasi (Hogg \& Terry, 2012).

Menurut Jackson \& Smith, individu perlu memandang dirinya sendiri sebagai bagian dari organisasi dan mengevaluasi untuk meningkatkan komitmen terhadap kelompok (Baron \& Byrne, 2004). RS memandang dirinya memang memiliki keinginan untuk masuk di organisasinya. Namun, ia hanya bisa pasrah dengan lingkungannya. Sementara itu, SF merasa mendapat keluarga kedua di organisasinya.

SF merasa antara pengurus junior dan senior pun juga saling mengayomi dan membimbing. Tidak hanya itu, kenyamanan yang dirasakan SF juga dari kesamaan tujuan berorganisasi dengan pengurus lain. Hal tersebut menunjukkan bahwa semakin individu menilai tinggi keanggotaan mereka dalam kelompok, semakin termotivasi mereka untuk bekerja dalam kelompok, sehingga kohesi kelompok menunjuk pada ikatan interpersonal anggota yang mengikat suatu kelompok untuk bersama-sama (Forsyth, 2006).

RS merasa takut tidak dianggap lingkungan sekitarnya, sehingga ia mengurangi nilai-nilai pribadinya agar diterima di lingkungan sekitarnya. Bahkan, ia juga takut pengurus atau anggota lain tidak menyukainya. Sama halnya dengan SF, ia peka terhadap perubahan sikap di sekitar lingkungan organisasinya. Ia selalu menjaga sikap untuk dapat diterima di lingkungan organisasi. Hal ini menunjukkan bahwa RS dan SF mengategorikan diri mereka dengan mengurangi nilai pribadi dalam meningkatkan identitas sosial mereka (Kite \& Whitley, Jr, 2016).

SF merasa menjadi bagian dari organisasi ketika melihat pengurus lain ada yang berprestasi. Ketika ada pengurus lain yang berprestasi baik nasional maupun internasional, SF menjadi sangat bangga menjadi bagian dari organisasi.

RS merasa biasa saja jika ada perbedaan antara nilai pribadi dengan nilainilai organisasi. Namun, ia memiliki nilai pribadi yang tidak ada di organisasinya seperti pendekatan interpersonal dan pemikiran untuk organisasi ke depannya. $\mathrm{Hal}$ ini menunjukkan pengoptimalisasi ciri khas, di mana RS mengidentifikasi dengan kelompok yang memberikan keseimbangan paling memuaskan antara identitas pribadi dan identitas kelompok (Kite \& Whitley, Jr, 2016).

Menurut Haslam (2004), dalam identitas sosial anggota harus memiliki kesamaan antar anggota dalam suatu kelompoknya. RS merasa memiliki kesamaan dengan pengurus lain terlebih faktor lingkungan sekitarnya. RS menjadi bagian dari organisasinya, karena berada di mayoritas lingkungannya pelajar Muhammadiyah.

RS dan SF sering intropeksi diri. Saat evaluasi perjalanannya di organisasi IPM, ia juga membutuhkan pengurus atau anggota lain untuk menilai dirinya. Selain itu, meminta senior memberikan masukan. Evaluasi diri tersebut dapat meningkatkan komitmen terhadap kelompok (Forsyth, 2006). 


\section{Simpulan dan Saran}

Berdasarkan penelitian yang sudah dilakukan dapat disimpulkan bahwa:

1. Hasil penelitian yang didapatkan peneliti adalah keempat subjek memiliki kesamaan terkait persepsi terhadap organisasi lain. Persepsi tersebut adalah organisasinya dengan organisasi lain sama saja memiliki ajaran yang bersumber dari agama Islam. Akan tetapi, mereka menilai setiap organisasi masing- masing memiliki ciri khas, seperti tempat berdakwahnya yang berbeda. Organisasi Muhammadiyah berdakwah dari kota, sehingga lebih modern. Sebaliknya, organisasi Nahdlatul Ulama dari desa, sehingga lebih tradisional.

2. Persepsi orang lain terhadap organisasi keempat subjek terbagi menjadi dua, dari pandangan positif dan pandangan negatif. Pandangan positifnya adalah kegiatan yang diadakan oleh organisasi selalu menarik. Sementara itu, pandangan negatifnya adalah ketidaksukaan orang lain dari segi amalan dan pimpinan organisasi.

3. Keempat subjek memiliki latar belakang yang sama terkait daya tarik terhadap organisasi. Daya tarik terbesar terdapat pada pengaruh dari kerabat keluarga dan juga ketertarikan terhadapkegiatankegiatan yang diselenggarakan dari masing-masing organisasi mereka. Selain itu, kedua subjek dari IPNU dan IPM menyukai cara berbicara pengurus di organisasi yang tegas, sopan dan santun.

4. Keempat subjek bersama pengurus lainnya dalam bekerja di organisasi saling membantu dan saling melengkapi, lebih peduli pada orang lain, saling mengingatkan sesama pengurus, dan berbagi ilmu dengan anggota organisasi lain.

5. Keempat subjek menyadari bahwa mereka belum sepenuhnya menerapkan nilai-nilai organisasi mereka masing- masing. Mereka sempat mengurangi nilai-nilai pribadi untuk dapat diterima di lingkungan organisasinya, namun mereka juga menambahkan nilai-nilai pribadi mereka yang belum ada di organisasi. Selain itu, walau mereka belum maksimal, mereka tetap berusaha untuk mematuhi dan mengamalkan nilainilai organisasi.

6. Kesamaan tersebut adalah tempat sekolah, tempat tinggal, pola pemikiran dan kesamaan tujuan berorganisasi dengan pengurus lain.

7. Keempat subjek mengidentifikasi dan mengategorikan diri mereka ke dalam lingkungan sosial yang memberikan hasil bahwa mereka bangga terhadap organisasi mereka.

Berdasarkan kesimpulan dari penelitian yang sudah dilakukan, maka saran yang dapat diberikan sebagai berikut:

1. Bagi informan dapat mematuhi peraturan organisasi, memaksimalkan nilai-nilai organisasi untuk diterapkan dalam kehidupan sehari-hari, dan tetap mempertahankan hubungan yang baik dalam in-group maupun out-group.

2. Bagi organisasi dapat menjadi acuan literatur dalam mengembangkan organisasi mereka. Selain itu, penelitian ini dapat digunakan untuk menyesuaikan kembali kegiatan-kegiatan atau program kerja di organisasi dengan nilai-nilai organisasi yang berlaku.

3. Bagi peneliti yang akan melakukan penelitian serupa, peneliti selanjutnya dapat melakukan pengambilan semua data secara luring, sehingga peneliti juga dapat melakukan observasi.

\section{Daftar Pustaka}

Absari, A. (2013). Identitas Sosial Penggemar K-Pop: Perbandingan antara Penggemar K-Pop yang Tergabung dalam Komunitas KFM dan Penggemar K-Pop yang tidak 
Tergabung dalam Komunitas KFM. Malang: Etheses UIN Malang.

Aisyah, B. (2018). Pengaruh Agama sebagai Identitas Sosial terhadap Rejection Sensitivity pada Mahasiswa Beragama Minoritas. Psychopreneur Journal, 19-29. Ali, H. (2010).

Jumlah Anggota Muhammadiyah dan Nahdlatul Ulama. Lembaga Survei Nasional.

Anindyajati, P. D. (2013). Status Identitas Remaja Akhir: Hubungannya dengan Gaya Pengasuhan Orangtua dan Tingkat Kenakalan Remaja. Character, 1, 1-5.

Anonim. (1997). IPM. Diakses pada tanggal 28 Oktober 2019 dari m.muhammadiyah.or.id: m.muhammadiyah.or.id

Anonim. (14 Mei 2019). Krisis Identitas pada Remaja. Diakses pada tanggal 28 Oktober 2019 dari Kompasiana.com.

Baron, R., \& Byrne, D. (2004). Psikologi Sosial Jilid 1. Jakarta: Erlangga.

Creswell, J. (2014). Research Design: Qualitative, Quantitative, and Mixed Methods Approaches. London: SAGE.

Denzin, N., \& Lincoln, Y. (2009). Handbook of Qualitative Research (terjemahan). Yogyakarta: Pustaka Pelajar

Erik. H, E. (1974). Identity: Youth and Crisis. London: Faber \& Faber, 3 Queen Square.

Forsyth, D. R. (2006). Group Dynamics. United State: Wadsworth.

Hasan, Ayyub, \& Syamwil. (n.d.). IPNU. Diakses pada tanggal 17 November 2019 dari IPNU.or.id.

Haslam, S. A. (2004). Psychology in Organizations, "The Social Identity Approach". London: SAGE.
Hogg, M., \& Terry, D. (2012). Social Identity Processes in Organizational Contexts. New York: Psychology Press, Taylor \& Francis Group.

Khoirudin, A. (15 Mei 2016). IPM. Retrieved from ipm.or.id: ipm.or.id

Kite, M. E., \& Whitley, Jr, B. (2016). Psychology of Prejudice and Discrimination: 3rd Edtion. New York: Routledge, Taylor \& Francis Group.

Miles, M., \& Huberman, A. (1992). Analisis Data Kualitatif. Jakarta: UI Press.

Muslim, A. (2013). Interaksi Sosial dalam Masyarakat Multietinis. Jurnal Diskursus Islam, 484-494.

Rudi, A. (2013). Selain Tradisi Kekerasan, Ini Penyebab lain Tawuran Pelajar. Retrieved from Kompas.com.

Santrock, J. W. (2004). Psikologi Pendidikan. Jakarta: Prenadamedia Group.

Utami, F. N., \& Silalahi, B. Y. (2013). Hubungan Antara Identitas Sosial dan Konformitas pada Anggota Komunitas Virtual Kaskus Regional Depok. Proceeding PESAT, 93-98. 